\title{
Interannual surface evolution of an Antarctic blue-ice moraine using multi-temporal DEMs
}

\author{
Matthew J. Westoby ${ }^{1}$, Stuart A. Dunning ${ }^{2}$, John Woodward ${ }^{1}$, Andrew S. Hein ${ }^{3}$, Shasta M. Marrero ${ }^{3}$, \\ Kate Winter ${ }^{1}$, and David E. Sugden ${ }^{3}$ \\ ${ }^{1}$ Department of Geography, Engineering and Environment, Northumbria University, Newcastle upon Tyne, UK \\ ${ }^{2}$ School of Geography, Politics and Sociology, Newcastle University, Newcastle upon Tyne, UK \\ ${ }^{3}$ School of GeoSciences, University of Edinburgh, Edinburgh, UK \\ Correspondence to: Matthew J. Westoby (matt.westoby@northumbria.ac.uk)
}

Received: 29 October 2015 - Published in Earth Surf. Dynam. Discuss.: 18 November 2015

Revised: 27 April 2016 - Accepted: 6 June 2016 - Published: 30 June 2016

\begin{abstract}
Multi-temporal and fine-resolution topographic data products are increasingly used to quantify surface elevation change in glacial environments. In this study, we employ 3-D digital elevation model (DEM) differencing to quantify the topographic evolution of a blue-ice moraine complex in front of Patriot Hills, Heritage Range, Antarctica. Terrestrial laser scanning (TLS) was used to acquire multiple topographic datasets of the moraine surface at the beginning and end of the austral summer season in 2012/2013 and during a resurvey field campaign in 2014. A complementary topographic dataset was acquired at the end of season 1 through the application of structure from motion with multi-view stereo (SfM-MVS) photogrammetry to a set of aerial photographs acquired from an unmanned aerial vehicle (UAV). Three-dimensional cloud-to-cloud differencing was undertaken using the Multiscale Model to Model Cloud Comparison (M3C2) algorithm. DEM differencing revealed net uplift and lateral movement of the moraine crests within season 1 (mean uplift $\sim 0.10 \mathrm{~m}$ ) and surface lowering of a similar magnitude in some inter-moraine depressions and close to the current ice margin, although we are unable to validate the latter. Our results indicate net uplift across the site between seasons 1 and 2 (mean $0.07 \mathrm{~m}$ ). This research demonstrates that it is possible to detect dynamic surface topographical change across glacial moraines over short (annual to intra-annual) timescales through the acquisition and differencing of fine-resolution topographic datasets. Such data offer new opportunities to understand the process linkages between surface ablation, ice flow and debris supply within moraine ice.
\end{abstract}

\section{Introduction}

Fine-resolution topographic data products are now routinely used for the geomorphometric characterization of Earth surface landforms (e.g. Passalacqua et al., 2014, 2015; Tarolli, 2014). Recent decades have seen the advent and uptake of a range of surveying technologies for characterizing the form and evolution of Earth surface topography on macro- (landscape; kilometres), meso- (landform; metres) and microscales (patch-scale; centimetre-millimetre). These technologies have included, amongst others, the use of satellite remote-sensing techniques (e.g. Kääb, 2002; Smith et al., 2006; Farr et al., 2007; Stumpf, 2014; Noh and Howat, 2015), as well as field-based surveying platforms such as electronic distance metres (total station; e.g. Keim et al., 1999; Fuller et al., 2003), differential global positioning systems (dGPSs; e.g. Brasington et al., 2000; Wheaton et al., 2010), terrestrial laser scanning (TLS; e.g. Rosser et al., 2005; Hodge et al., 2009), airborne light detection and ranging (lidar; e.g. Bollmann et al., 2011), and soft copy or digital photogrammetry (e.g. Micheletti et al., 2015).

More recently, geoscientists have increasingly been adopting low-cost structure from motion with multi-view stereo (SfM-MVS) methods, which employ computer vision and multi-view photogrammetry techniques to recover surface topography using optical (e.g. James and Robson, 2012; 
Westoby et al., 2012; Javernick et al., 2014; Micheletti et al., 2014; Woodget et al., 2015; Smith and Vericat, 2015) or thermal imagery (e.g. Lewis et al., 2015). Concomitant developments in lightweight unmanned aerial vehicle (UAV) technology, specifically decreasing system costs, increased portability and improvements in the accessibility of flight planning software, have encouraged the acquisition of repeat, fine-resolution (metre to centimetre) topographic data products from low-altitude aerial photography platforms (e.g. Niethammer et al., 2010; Ouédraogo et al., 2014; Bhardwaj et al., 2016). Furthermore, the differencing of topographic datasets acquired at different times is now an established method for quantifying the transfer of mass and energy through landscapes on the spatial scales of observation at which many processes operate (Passalacqua et al., 2015).

Fine-resolution topographic datasets produced using airborne or ground-based lidar, or terrestrial or low-altitude aerial digital photogrammetry, have been used for a diverse range of applications in various glacial, proglacial and periglacial environments on a range of scales, including the quantification of ice surface evolution (e.g. Baltsavias et al., 2001; Pitkänen and Kajuutti, 2004; Keutterling and Thomas, 2006; Schwalbe and Maas, 2009; Immerzeel et al., 2014; Pepin et al., 2014; Whitehead et al., 2014; Gabbud et al., 2015; Kraaijenbrink et al., 2016; Piermattei et al., 2015; Ryan et al., 2015; Kääb et al., 2014); mapping the redistribution of proglacial sediment (e.g. Milan et al., 2007; IrvineFynn et al., 2011; Dunning et al., 2013; Staines et al., 2015) and moraine development (Chandler et al., 2015); the characterization of glacier surface roughness (e.g. Sanz-Ablanedo et al., 2012; Irvine-Fynn et al., 2014), glacial sedimentology (Westoby et al., 2015) and hydrology (Rippin et al., 2015) as well as input data for surface energy balance modelling (e.g. Arnold et al., 2006; Reid et al., 2012); and for characterizing glacial landforms in formerly glaciated landscapes (e.g. Smith et al., 2009; Tonkin et al., 2014; Hardt et al., 2015).

In this study, we utilize fine-resolution topographic datasets to quantify the surface evolution of a blue-ice moraine complex in a remote part of Antarctica. Blue-ice areas cover approximately $1 \%$ of Antarctica's surface area (Bintanja, 1999), yet they remain relatively understudied. Relict blue-ice moraines preserved on nunataks are key indicators of ice sheet elevation changes; however, limited data exist on rates and patterns of surface reorganization, which may be of use for contextualizing the results of, for example, cosmogenic nuclide dating and geomorphological mapping (Hein et al., 2016). This research seeks to quantify the shortterm surface evolution of a moraine complex in Patriot Hills, Heritage Range, Antarctica (Fig. 1), through the differencing and analysis of multi-temporal topographic datasets acquired using TLS and the application of SfM-MVS photogrammetry to optical imagery acquired from a low-altitude UAV sortie.

\section{Study site}

The study site is a blue-ice moraine complex, located on the northern flank of the Patriot Hills massif at the southernmost extent of Heritage Range, West Antarctica (Fig. 1). Blue-ice moraine formation is hypothesized to be the result of preferential ablation of marginal ice by katabatic winds, which in turns prompts the modification of ice flow and englacial sediment transport pathways such that basal sediment is brought to the ice surface, where it is deposited (e.g. Bintanja, 1999; Sinisalo and Moore, 2010; Fogwill et al., 2012; Spaulding et al., 2012; Hein et al., 2016). The site comprises a series of broadly east-west-oriented moraine ridges and inter-moraine troughs, as well as an area of subdued moraine topography immediately adjacent to the ice margin (Fig. 2). At this location, the active blue-ice moraines occupy an altitudinal range of $60-70 \mathrm{~m}$ above the ice margin $(\sim 730 \mathrm{~m}$ a.s.l.) and extend for a distance of up to $350 \mathrm{~m}$ into a bedrock embayment (Fig. 1). The blue-ice moraines can be traced for a distance of $>4 \mathrm{~km}$ to the east and north-east, parallel to the range front, and fill ice-marginal embayments. The site is geomorphologically and sedimentologically complex (e.g. Vieira et al., 2012; Westoby et al., 2015) and, along with moraine ridges and troughs, includes areas of subdued ice-marginal topography with thermokarst melt ponds, local gullying and crevassing on ice-proximal and distal moraine flanks, as well as solifluction deposits at the base of the surrounding hillslopes. The bedrock hillslopes are overlain by a till drape with rare, large exotic sandstone boulder erratics which have some evidence of periglacial reworking. Field observations suggest that the blue-ice moraines are dynamic features which are undergoing localized surface changes. It is these short-term, changes which are the subject of investigation in this paper.

\section{Methods and data products}

This research employs two methods for reconstructing moraine surface topography, specifically TLS and SfM-MVS photogrammetry. Two field campaigns at Patriot Hills were undertaken with a 12-month survey interval. Briefly, TLS data were acquired at the beginning and end of austral summer season 1 (December 2012 and January 2013, respectively) and in a short resurvey visit in season 2 (January 2014). Low-altitude aerial optical photography was acquired from a UAV at the end of season 1 and was used as the primary input to SfM-MVS processing. The following sections detail the two methods of topographic data acquisition, data processing and subsequent analysis using cloud-to-cloud differencing. 

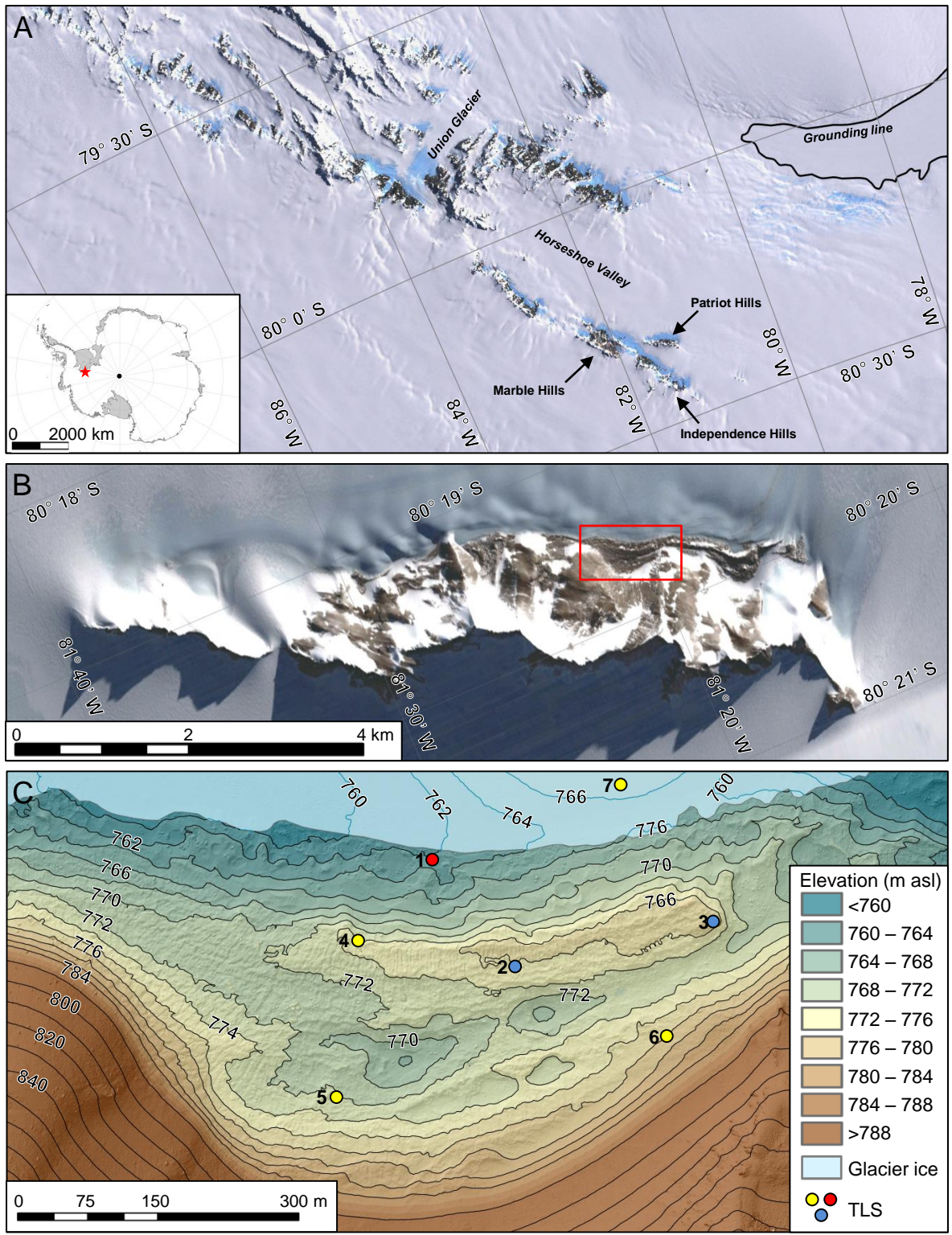

Figure 1. Blue-ice moraine embayment, Patriot Hills, Heritage Range, Antarctica. (a) Geographical context of Patriot Hills within the Heritage Range, southern Ellsworth Mountains. (b) The Patriot Hills massif. The location of the study embayment and area displayed in (c) is highlighted in red. (c) Detailed study site overview map. Contours and underlying hillshade are derived from a UAV-SfM-derived digital elevation model (DEM). TLS positions for the start of season 1 are shown in red, blue and yellow. The two scan positions reoccupied at the end of season 1 are shown in blue, whilst the three scan positions reoccupied in season 2 are shown in blue and red. Background to (a) ${ }^{\circledR}$ U.S. Geological Survey; background (b) ${ }^{\circledR} 2015$ DigitalGlobe; both extracted from Google Earth.

\subsection{Topographic data acquisition}

\subsubsection{Terrestrial laser scanning}

TLS data were acquired using a Riegl LMS-Z620 time-offlight laser scanner, set to acquire $\sim 11000$ points per second in the near-infrared band at horizontal and vertical scanning increments of $0.031^{\circ}$, equivalent to a point spacing of $0.05 \mathrm{~m}$ at a distance of $100 \mathrm{~m}$ and with a beam divergence of $15 \mathrm{~mm}$ per $100 \mathrm{~m}$. Data were acquired from six locations across the site at the beginning of season 1 (7-11 December 2012; Fig. 1; Table 1). Two of these positions were reoccupied at the end of season 1 (9 January 2013) and three positions were reoccupied in season 2 (Fig. 1; 14 January 2014). Following manual editing and the automated removal of isolated points to improve data quality, each set of scans was co-registered in Riegl RiSCAN PRO software (v. 1.5.9) using a two-step procedure employing coarse manual pointmatching followed by the application of a linear, iterative, 
least-squares minimization solution to reduce residual alignment error. Individual scans were then merged to produce a single 3-D point cloud for each scan date. Merged scan data from the end of seasons 1 and 2 were subsequently registered to the scan data from the beginning of season 1 using the methods described above (Table 1).

\subsubsection{Structure from motion with multi-view stereo photogrammetry}

Low-altitude aerial photographs of the study site were acquired using a 10-Megapixel Panasonic Lumix DMC-LX5 compact digital camera with a fixed focal length $(8 \mathrm{~mm})$ and automatic exposure settings, mounted in a fixed, downwardfacing (nadir) perspective on a sub-5 kg fixed-wing UAV. Photographs were acquired in a single sortie lasting $\sim 5 \mathrm{~min}$. A total of 155 photographs were acquired at a $2 \mathrm{~s}$ interval at an approximate ground height of $120 \mathrm{~m}$, producing an average image overlap of $80 \%$ and an approximate ground resolution of $0.07 \mathrm{~m}^{2}$ per pixel. Mean point density was $\sim 300$ points $\mathrm{m}^{-2}$, compared to a mean of 278 points $\mathrm{m}^{-2}$ for the TLS datasets. Motion blur of the input images was negligible due to favourable image exposure conditions and an appropriate UAV flying height and speed.

UAV photographs were used as input to SfM reconstruction using the proprietary Agisoft PhotoScan Professional Edition (2015, v. 1.1.6) software. Unique image tie points which are stable under variations in view perspective and lighting were identified and matched across input photographs, similar to Lowe's (2004) Scale Invariant Feature Transform (SIFT) method. An iterative bundle adjustment algorithm was used to solve for internal and external camera orientation parameters and produce a sparse 3-D point cloud. The results of the first-pass camera pose estimation were scrutinized and only 3-D points which appear in a minimum of three photographs and possessed a reprojection error of $<1.0$ were retained. A two-phase method of UAV-SfM data registration was employed:

1. Ground control was obtained by identifying common features in the UAV-SfM photographs and TLS data from the end of season 1 (acquired 4 days after the SfM data; Table 1), such as the corners of large, wellresolved boulders or bedrock outcrops. Ground control point (GCP) data were used to optimize the initial camera alignment and transform the regenerated UAV-SfM data to the same object space as the TLS data, producing an $x y z$ rms error of $0.23 \mathrm{~m}$.

2. Following dense reconstruction using Multi-View Stereo methods, 3-D point data were exported to RiSCAN PRO (v. 1.5.9) software, and a linear, iterative, least-squares minimization employing surface plane matching was used to improve the alignment and reduce the $x y z$ rms error to $0.03 \mathrm{~m}$.

\subsection{Cloud-to-cloud differencing}

Three-dimensional cloud-to-cloud distance calculations were used to quantify moraine surface evolution (e.g. Lague et al., 2013). Since the dominant direction of surface evolution across the study site was unknown a priori, the application of an algorithm that is capable of detecting fully threedimensional topographic change was deemed to be the most appropriate method in this context. To this end, we employ the Multiscale Model to Model Cloud Comparison (M3C2) algorithm (Lague et al., 2013; Barnhart and Crosby, 2013), implemented in the open-source CloudCompare software (v. 2.6.1) for change detection.

The M3C2 algorithm implements two main processing steps to calculate 3-D change between two point clouds: (1) estimation of surface normal orientation on a scale consistent with local surface roughness and (2) quantification of the mean cloud-to-cloud distance (i.e. surface change) along the normal direction (or orthogonal vector), which includes an explicit calculation of the local confidence interval. A point-specific normal vector is calculated by fitting a plane to neighbouring 3-D points that are contained within a userspecified search radius. To avoid the fluctuation of normal vector orientations and a potential overestimation of the distance between two point clouds, the radius, or scale, used for normal calculation needs to be larger than the topographic roughness, which is calculated as the standard deviation of local surface elevations $(\sigma)$. The orientation of the surface normal around a point, $i$, is therefore dependent on the scale at which it is computed (Lague et al., 2013). A trial-and-error approach was employed to reduce the estimated normal error, $E_{\text {norm }}(\%)$, through refinement of a rescaled measure of $D$, $\xi$, where

$\xi(i)=\frac{D}{\sigma_{i}(D)}$.

Using this rescaled measure of $D, \xi$ can be used as an indicator of estimated normal orientation accuracy, such that where $\xi$ falls in the range $\sim 20-25$, the estimated normal error is $E_{\text {norm }}<2 \%$ (Lague et al., 2013). A fixed normal scaling of $2 \mathrm{~m}$ was found to be sufficient to ensure that $\xi>20$ for $>98 \%$ of points in each topographic dataset.

The radius of the projection cylinder, $d$, within which the average surface elevation of each cloud is calculated, was specified as $2 \mathrm{~m}$. This scaling ensured that the number of points sampled in each cloud was $\geq 30$, following guidance provided by Lague et al. (2013). M3C2 execution took $\sim 0.3 \mathrm{~h}$ for each differencing task on a desktop computer operating with $32 \mathrm{~GB}$ of RAM and a $3.4 \mathrm{GHz}$ CPU. Cloud-tocloud distances and statistics were projected onto the original point cloud. $\mathrm{M} 3 \mathrm{C} 2$ output was subsequently masked to exclude points where change is lower than level of detection threshold for a $95 \%$ confidence level, $L o D_{95} \%(d)$, which is 

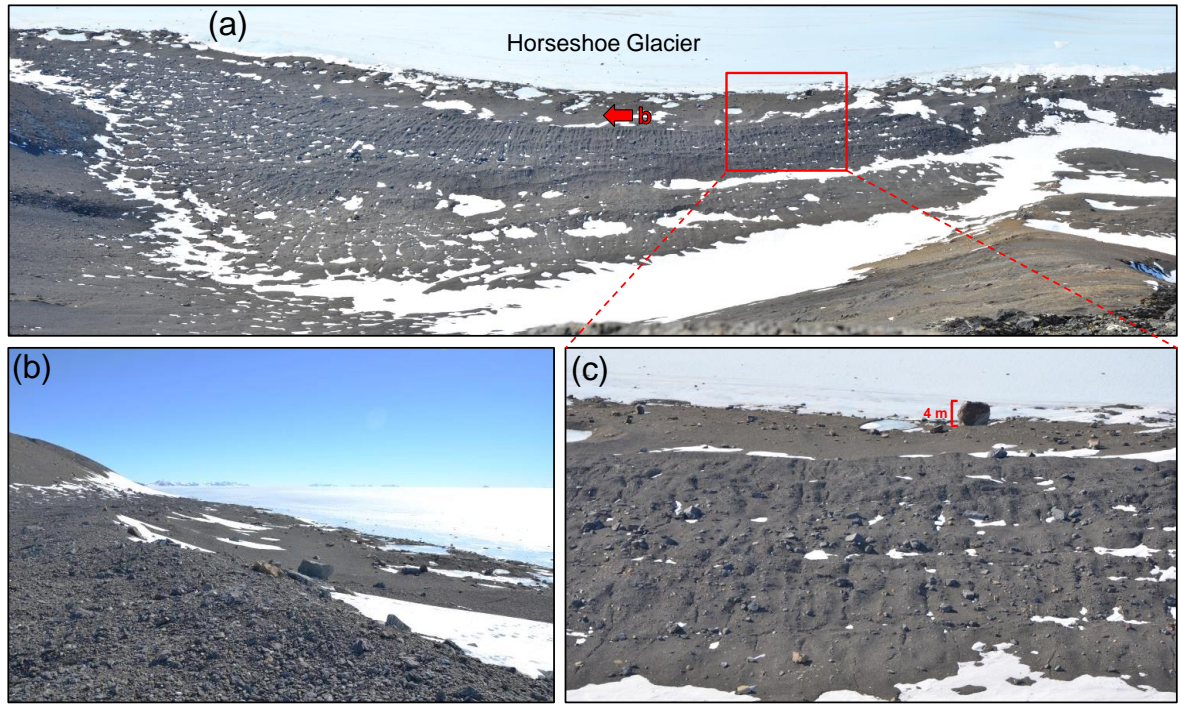

Figure 2. Field photographs of the Patriot Hills blue-ice moraine study site. (a) Panoramic photograph of the moraine embayment - view north-east towards the ice margin from the rear of the embayment. Area shown in (c) and position and view direction of camera (b) shown for reference. (b) View to the north-west with moraine crest in foreground and subdued, ice-marginal moraine surface topography in middle ground. (c) Close-up of moraine topography, highlighting ridges and furrows on moraine crests and in inter-moraine troughs.

Table 1. Terrestrial laser scanning and UAV-SfM survey dates and registration errors. Within each season, individual scans were registered to a single static position to produce a single, merged point cloud (scan-scan registration error). TLS data from the end of season 1 and for season 2 were subsequently registered to TLS data acquired at the start of season 1, producing a project-project registration error. The UAV-SfM data (season 1 end) were registered to TLS data from the end of season 1.

\begin{tabular}{|c|c|c|c|c|}
\hline Field survey & $\begin{array}{c}\text { Scan } \\
\text { position }\end{array}$ & $\begin{array}{l}\text { Scan } \\
\text { date }\end{array}$ & $\begin{array}{r}\text { Scan-scan } \\
\text { registration error } \\
(\mathrm{rms} ; \mathrm{m})\end{array}$ & $\begin{array}{r}\text { Project-project } \\
\text { registration error } \\
(\mathrm{rms} ; \mathrm{m})\end{array}$ \\
\hline Season 1 start (TLS) & $\begin{array}{l}1 \\
2 \\
3 \\
5 \\
6 \\
7\end{array}$ & $\begin{array}{l}\text { 07 Dec } 2012 \\
\text { 08 Dec } 2012 \\
\text { 08 Dec } 2012 \\
\text { 09 Dec } 2012 \\
\text { 01 Dec } 2012 \\
\text { 11 Dec } 2012\end{array}$ & $\begin{array}{r}\text { Static } \\
0.0327 \\
0.0391 \\
0.0301 \\
0.0258 \\
0.0258\end{array}$ & Static \\
\hline Season 1 end (TLS) & $\begin{array}{l}1 \\
2\end{array}$ & $\begin{array}{l}\text { 09 Jan } 2013 \\
\text { 09 Jan } 2013\end{array}$ & $\begin{array}{r}\text { Static } \\
0.0145\end{array}$ & 0.0145 \\
\hline Season 1 end (UAV-SfM) & - & 05 Jan 2013 & - & 0.0306 \\
\hline Season 2 (TLS) & $\begin{array}{l}1 \\
2 \\
3\end{array}$ & $\begin{array}{l}\text { 14 Jan } 2014 \\
\text { 14 Jan } 2014 \\
\text { 14 Jan } 2014\end{array}$ & $\begin{array}{r}\text { Static } \\
0.0205 \\
0.0255\end{array}$ & 0.0149 \\
\hline
\end{tabular}

defined as

$\operatorname{LoD}_{95 \%}(d)= \pm 1.96\left(\frac{\sigma_{1}(d)^{2}}{n_{1}}+\frac{\sigma_{2}(d)^{2}}{n_{2}}+\mathrm{reg}\right)$,

where $d$ is the radius of the projection cylinder, reg is the user-specified registration error, for which we substitute the propagated root mean square alignment error for point clouds $n_{1}$ and $n_{2}$ (Table 2; Eq. 1) and assume that this error is isotropic and spatially uniform across the dataset.

To calculate the total propagated error for each differencing epoch, $\sigma_{D o D}$, the estimates of errors in each point cloud (i.e. the sum of the average scan-scan rms error and a 
Table 2. Registration error propagation for specific differencing epochs. The propagated error for each differencing epoch is calculated using Eq. 3. The $95 \%$ level of detection or detection threshold is calculated in M3C2 as the product of the propagated error and a measure of local point cloud roughness (Lague et al., 2013). The results of 3-D differencing were filtered in CloudCompare so that only differences larger than the most conservative (largest) $L_{0 D}$ \% (i.e. $0.103 \mathrm{~m}$ ) were considered to represent significant change.

\begin{tabular}{lcc}
\hline Differencing epoch & Propagated error (rms; m) & M3C2 \\
Lo $D_{95 \%}(\mathrm{~m})$ \\
\hline S1 start (TLS)-S1 end (TLS) & 0.049 & 0.098 \\
S1 start (TLS)-S1 end (SfM) & 0.050 & 0.103 \\
S1 end (TLS)-S2 end (TLS) & 0.048 & 0.098 \\
S1 end (SfM)-S2 end (TLS) & 0.049 & 0.102 \\
S1 start (TLS)-S2 end (TLS) & 0.050 & 0.099 \\
\hline
\end{tabular}

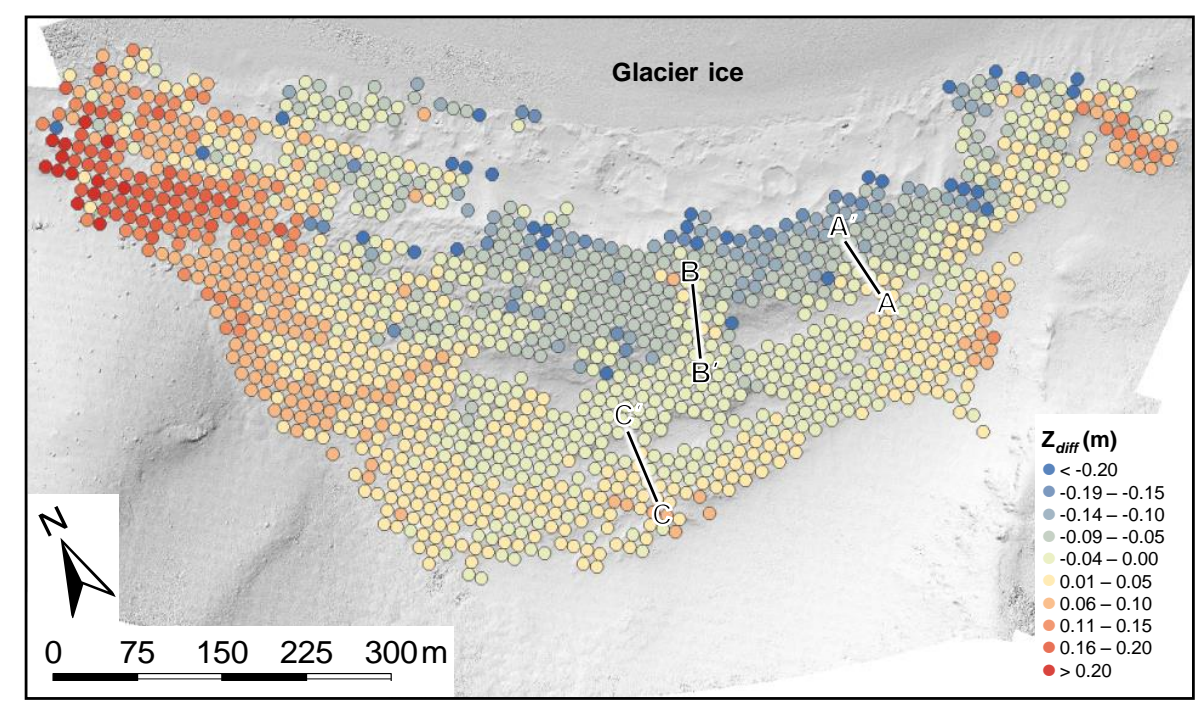

Figure 3. Results of vertical $\left(Z_{\mathrm{diff}} ; \mathrm{m}\right)$ differencing of the UAV-SfM and TLS datasets acquired at the end of season 1, represented as the mean difference within $10 \mathrm{~m}^{2}$ grid cells. Overall, $83 \%$ of the UAV-SfM data were found to be within $\pm 0.1 \mathrm{~m}$ of the equivalent TLS data. Profiles A-C are displayed in Fig. 4.

project-project rms error, where applicable) were combined using

$\sigma_{D o D}=\sqrt{\sigma_{C_{1}}^{2}+\sigma_{C_{2}}^{2}}$

where $\sigma_{C_{1}}^{2}$ and $\sigma_{C_{2}}^{2}$ are the rms errors associated with point clouds $C_{1}$ and $C_{2}$.

\subsection{Data intercomparison: SfM vs. TLS}

Whilst the UAV-SfM dataset acquired at the end of season 1 significantly improves on the spatial coverage afforded by the use of TLS across the moraine embayment, an analysis of the relative accuracy of the reconstructed surface topography of the former is required. To this end, Fig. 3 shows the results of vertical differencing of the UAV-SfM and TLS data and is complemented by a series of surface elevation profiles (Fig. 4). These results reveal that $83 \%$ of the UAV-SfM data are within $\pm 0.1 \mathrm{~m}$ of the equivalent TLS data when gridded as the mean of vertical displacement in $10 \mathrm{~m}^{2}$ grid cells.
However, two zones of substantial vertical discrepancy exist, namely the northernmost (ice-marginal) sector of the site, where the UAV-SfM data locally underestimate the equivalent TLS surface elevation by $<-0.20 \mathrm{~m}$ (mean $-0.13 \mathrm{~m}$ ), and a zone to the north-west of the site, where the UAV-SfM data locally overestimate the TLS ground surface elevation by $>0.20 \mathrm{~m}$ (mean $0.12 \mathrm{~m}$ ). We propose two explanations for these vertical discrepancies. Firstly, it was difficult to identify corresponding features in the TLS and UAV-SfM datasets in the north-western sector of the site due to the sparsity of TLS data coverage here at the end of season 1 (cf. Fig. 5c and d). Secondly, the UAV executed sharp banking turns in this area of the site to clear a hillslope spur. These manoeuvres were difficult for the on-board camera stabilizing gimbal to compensate for, thereby reducing the effective side- and forward overlap of the aerial photography. Similar banking turns were carried out at the eastern edge of the site; however, it was possible to more confidently identify GCPs in the TLS data in this region, which appears to have had a mitigating effect on the effects of reduced image overlap on scene reconstruc- 


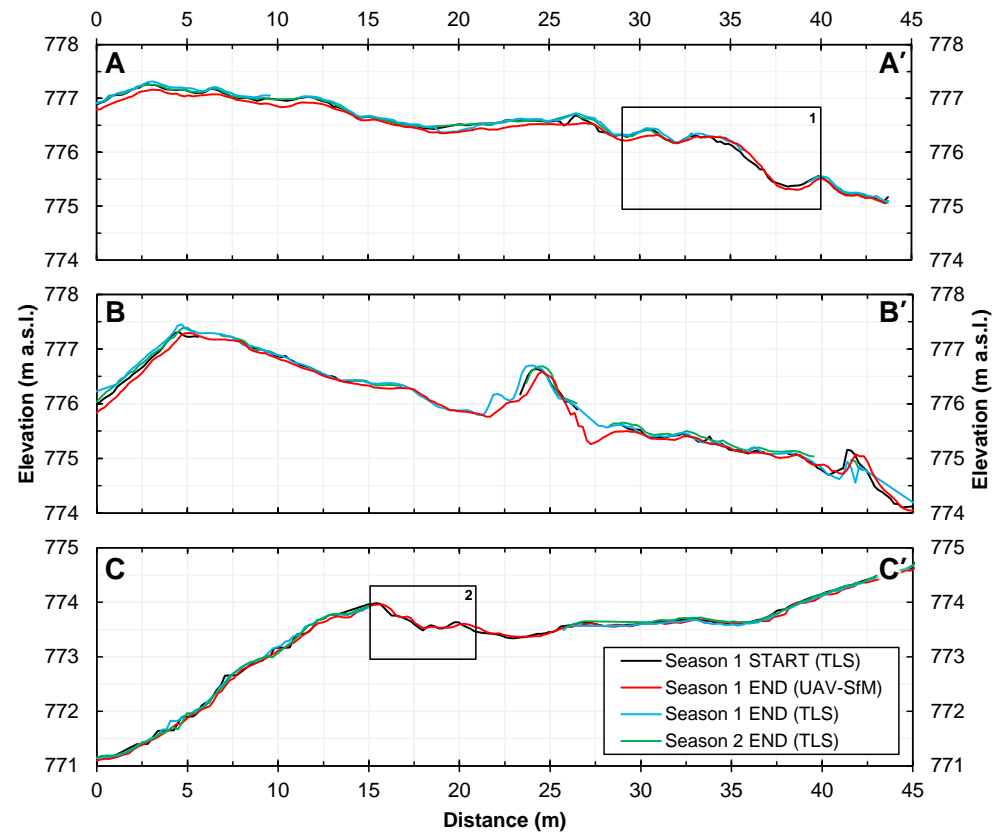

Figure 4. Moraine surface elevation profiles, extracted from gridded $\left(0.2 \mathrm{~m}^{2}\right)$ digital elevation models of TLS- and SfM-derived topographic datasets. Profile locations are shown in Figs. 3 and 6. Profiles A and B bisect the main central moraine crest, whilst profile C is located on moraine deposits at the back of the embayment. Inset numbered boxes in profiles $\mathrm{A}$ and $\mathrm{C}$ show areas referred to in the text.

tion. Finally, those features that did appear in the TLS data in this sector were typically near-vertical faces of large clasts which were oriented toward the scanner and which were not well-resolved in the UAV-SfM data due to its nadir perspective. This made the accurate identification of matching clast features or edges challenging. Ultimately, we attribute less confidence in both the geometric accuracy of the 3-D SfMMVS reconstruction and final model-to-model alignment in the north-western sector of the site.

We attribute underestimated UAV-SfM surface elevations in the centre-north of the site to also be a product of the differing spatial extents of the two datasets. In this location, the northernmost extent of the UAV-SfM data encompasses the entire ice-marginal zone, whereas the equivalent TLS data were truncated at the foot of the main moraine crest due to logistical constraints which precluded the acquisition of a more complete TLS dataset at the end of season 1. Since no robust GCPs could be identified in the TLS data for the ice-marginal zone for use in the UAV-SfM camera optimization and registration process, the ground surface geometry in this area tends towards a systematic negative elevation bias, possibly as the result of residual radial lens distortion following camera calibration in PhotoScan (e.g. James and Robson, 2014), which we were unable to compensate for.

Transect data also highlight areas of inconsistency, specifically often considerable offsets between the TLS and SfM data which were collected at the end of season 1 and which, in places, approach $0.5 \mathrm{~m}$ in magnitude (e.g. at $\sim 27 \mathrm{~m}$ distance in profile $\mathrm{A}$ and between 22 and $30 \mathrm{~m}$ in profile $\mathrm{B}$;
Fig. 4). An additional explanation for these inconsistencies could be the evolution of moraine surface topography in the 4-day interval which separated the acquisition of the TLS and SfM data at the end of season 1 (Table 1), with the implication that features used as GCPs in the TLS data and their counterparts in the UAV-SfM data were not static, thereby affecting the georeferencing and SfM optimization solution. However, since we observed no clustering of large GCP errors in areas of activity, as shown in the TLS-TLS differencing results, this factor is unlikely to account for these topographic inconsistencies.

Topographic mismatches between the TLS and UAV-SfM data also appear to be the most prominent in areas of steep topography (Figs. 3 and 4). These areas were generally wellresolved in the TLS data (where not topographically occluded) but may have been resolved in less detail and with less accuracy in the UAV-SfM data, where the fixed camera angle promotes the foreshortening of these steep slopes in the aerial photography. These differences might also be explained by the near-parallel and largely nadir view directions of the UAV imagery, which represent a "non-convergent" mode of photograph acquisition that has elsewhere been found to result in the deformation, or "doming", of SfMderived surface topography (e.g. James and Robson, 2014; Rosnell and Honkavaara, 2012; Javernick et al., 2014).

Model deformations can be countered to some degree through the inclusion of additional, oblique imagery and the use of a well-distributed and photo-visible GCP network (James and Robson, 2014). However, although the latter were 

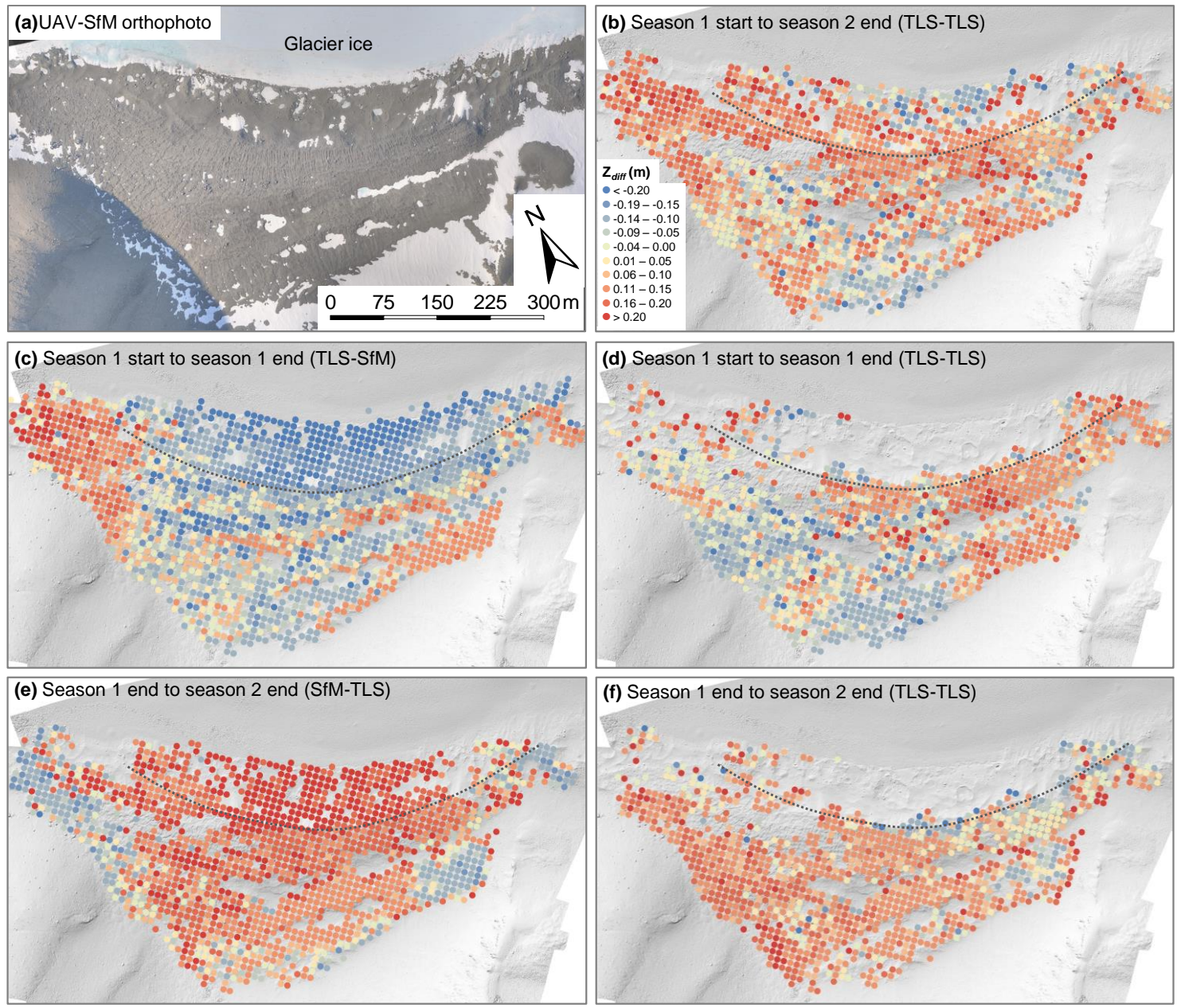

Figure 5. Vertical component of 3-D topographic change $\left(Z_{\text {diff }}\right)$ overlain on a UAV-SfM-derived hill-shaded DEM of the Patriot Hills blueice moraine complex. Topographic evolution was quantified using the Multiscale Model to Model Cloud Comparison (M3C2) algorithm in CloudCompare software. Vertical change is represented as the mean of significant change beyond a threshold of $\pm 0.103 \mathrm{~m}$ within $10 \mathrm{~m}^{2}$ grid cells. (a) UAV-SfM orthophotograph of the study site. Panels (b) to (f) cover specific differencing epochs using a combination of TLS and SfM data (see panel headings). Dashed line in (b) to (f) indicates locations of primary moraine ridge crest.

relatively evenly distributed across our study site, the inclusion of these data and subsequent use for the optimization of the SfM data prior to dense point cloud reconstruction does not appear to have altogether eliminated these model deformations. We discuss the implications of data quality issues for interpreting geomorphological process analysis in Sects. 4 and 5.

\section{Short-term topographic evolution of blue-ice moraines}

\subsection{Vertical displacement}

The results of 3-D cloud-to-cloud differencing are summarized in Fig. 5. Threshold levels of change detection ranged from 0.094 to $0.103 \mathrm{~m}$. The upper (i.e. most conservative) bound of this range was applied to the results from all dif- ferencing epochs, so that only 3-D surface change greater than $\pm 0.103 \mathrm{~m}$ was considered in the subsequent analysis. The horizontal (xy) and vertical (z) components of 3-D surface change were separated to aid the analysis and interpretation of moraine surface evolution and were gridded to represent the mean of significant change within regular $10 \mathrm{~m}^{2}$ grid cells to account for variations in point density across the site (Fig. 5, Fig. 6). Vertical surface change for a range of epochs, encompassing intra-annual and annual change, are displayed in Fig. 5, whilst illustrative horizontal components of 3-D change for intra- and interannual differencing epochs are shown in Fig. 6. The longest differencing epoch, representing a period of $\sim 400$ days (Fig. $5 b$ ), shows a broad pattern of net uplift across the moraine of the order of 0.074 $\mathrm{m}$. Locally, uplift exceeds $0.2 \mathrm{~m}$ across parts of the moraine complex, and, whilst on first glance these elevation gains appear to be largely randomly distributed across the site, on 


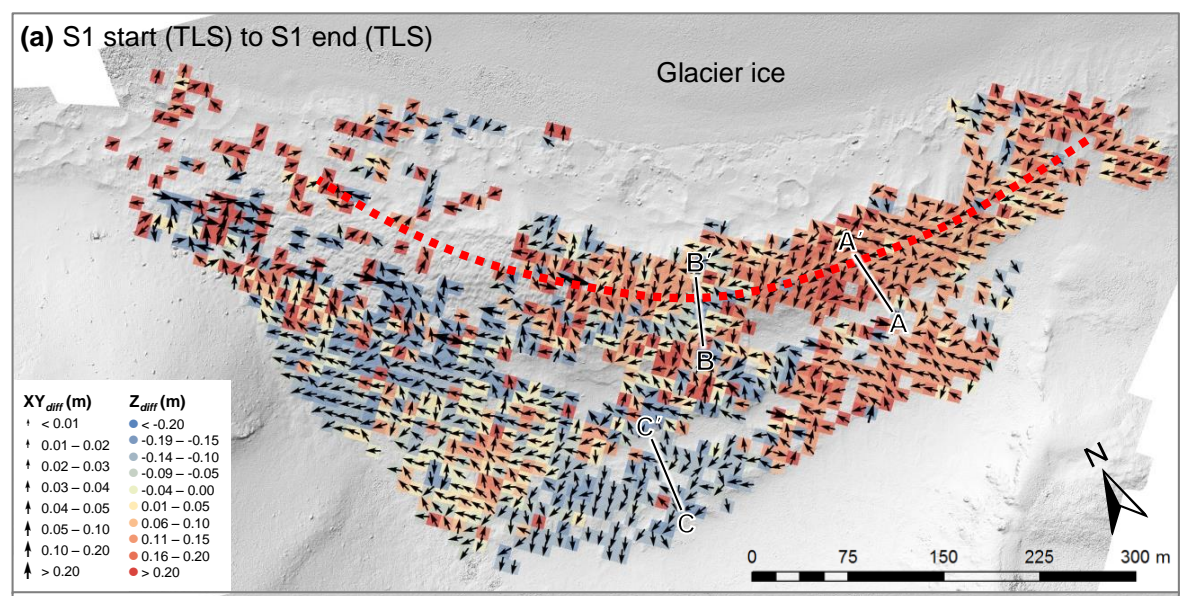

(b) S1 start (TLS) to S1 end (UAV-SfM)

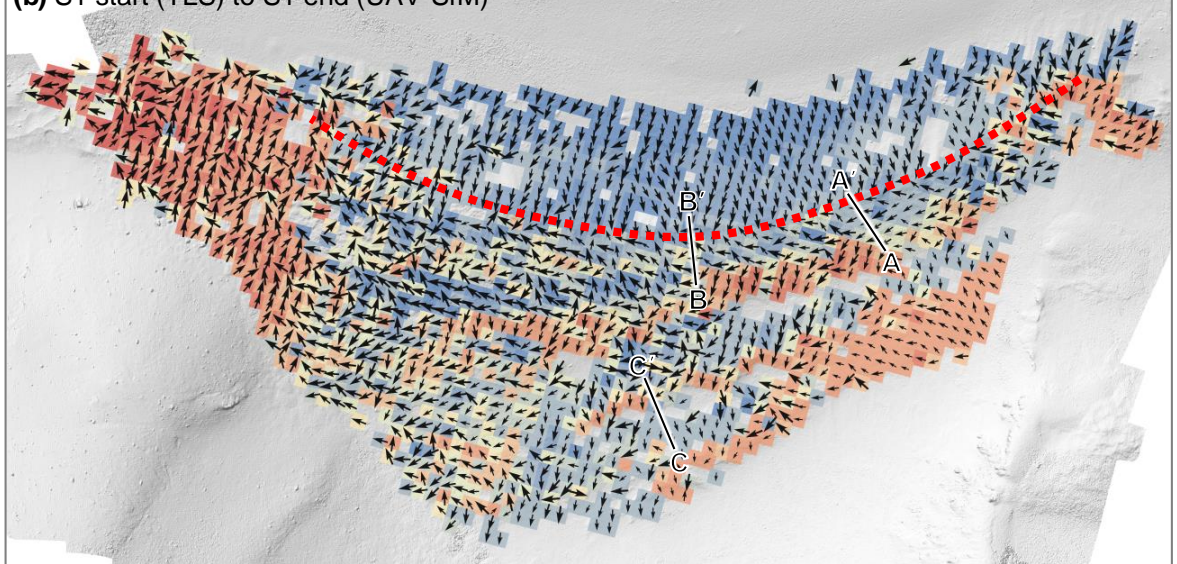

(c) S1 start (TLS) to S2 end (TLS)

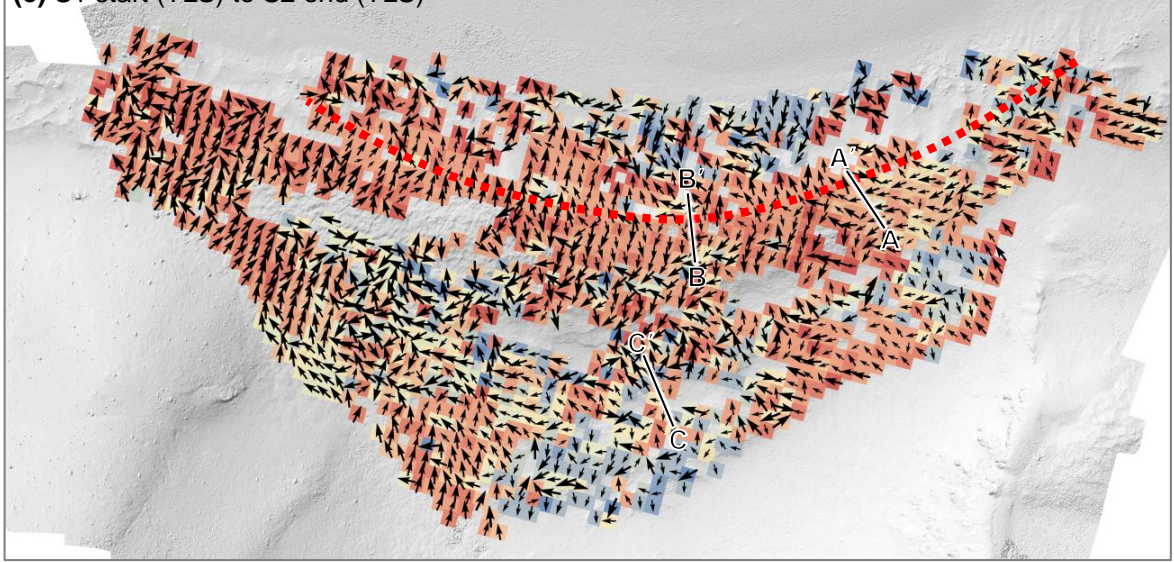

Figure 6. Change detection mapping for (a, b) intra-annual (season 1 start to season 1 end) and (c) annual (season 1 start to season 2 ) differencing epochs. Horizontal difference vectors $\left(X Y_{\text {diff }}\right)$ are scaled by magnitude and oriented according to the direction of change. The vertical component of 3-D change $\left(Z_{\text {diff }}\right)$ is shown in the background. Transects A-C denote the location of moraine surface profiles displayed in Figs. 3 and 4. Red dashes on all panels shows the approximate location of primary moraine ridge crest.

closer inspection they occur predominantly on or adjacent to the main, central moraine ridge and close to the current ice margin. The large central moraine ridge exhibits a mean uplift of $0.11 \mathrm{~m}$, whilst specific ice-marginal areas to the west and an area of moraine to the south-west of the embayment also exhibit uplift of a similar magnitude (Fig. 5b). In contrast, an area in the southernmost sector of the basin and an ice-marginal area to the centre-west exhibit a net reduction in moraine surface elevation, up to a maximum of $-0.354 \mathrm{~m}$. 
Intra-annual change detection mapping was undertaken using TLS-TLS and TLS-SfM differencing (Fig. 5c, d). Key similarities between these two datasets, which represent vertical topographic change over a $\sim 31$ - and $\sim 27$-day period, respectively, include uplift at the southern extent of the embayment (mean 0.081 and $0.123 \mathrm{~m}$ for the TLS-TLS and TLS-SfM differencing, respectively). Similarly, both datasets reveal surface lowering in the south-east, or true rear, of the basin (mean -0.106 and $-0.112 \mathrm{~m}$ for TLS-SfM and TLS-TLS differencing, respectively) and, in the TLS-SfM data, on the ice-distal (southern) side of the central moraine ridge (Fig. $5 \mathrm{c} ;-0.092 \mathrm{~m}$ ). However, the large area of icemarginal surface lowering $(-0.095$ to $-0.373 \mathrm{~m})$ that is detected in the TLS-SfM differencing results is not mirrored in the equivalent TLS-TLS differencing data (Fig. 5d) and stems in large part from the reduced spatial coverage of the usable TLS scan data acquired at the end of season 1, which comprised data from only two scan positions (Fig. 1c) and which omits the ice-marginal zone.

The results of vertical change detection using both SfMTLS and TLS-TLS approaches also display similarities for differencing undertaken between the end of season 1 and season 2 (Fig. 5e, f), including a largely continuous area of uplift across the centre of the site, as well as areas of surface lowering along the eastern edge of the site. Whilst widespread uplift characterizes the entire western edge of the study area in the TLS-TLS data (Fig. 5f), the equivalent SfM-TLS data instead report the occurrence of surface lowering at the base of the hillslope spur which forms the western boundary of the site (Fig. 5e). Furthermore, an area of considerable (mean $0.218 \mathrm{~m}$ ) uplift characterizes the ice-marginal zone in the SfM-TLS differencing data for this epoch, but, once again, the reduced spatial coverage of the TLS datasets mean that no differencing data are available to verify or contest this pattern. However, we note that vertical change at the ice-marginal (northern) limit of the TLS-TLS data for both intra-annual and annual differencing epochs does not correspond with the equivalent TLS-SfM or SfMTLS results (Fig. 5c and e, respectively).

In light of our discussion of the sources of substantial topographic discrepancy between the TLS and UAV-SfM datasets (Fig. 3; Sect. 3.3), important questions arise as to whether the differencing results in the ice-marginal zone and in the western sector of the site truly represent physical surface movement, both within season 1 and between seasons (Figs. 5 and 6). On balance, and despite the application of a sufficiently large confidence threshold to remove nonsignificant change from the differencing results (Table 2), we retain much less confidence in reported surface displacement in these two zones than we do for the central portion and rear arc of the moraine basin, where we note that the results of TLS-SfM and TLS-TLS differencing for near-identical differencing periods exhibit a number of similarities.

\subsection{Lateral displacement}

Examples of horizontal displacement, calculated here as the $x y$ component of the orthogonal distance between two point clouds acquired at separate times and gridded to represent the average $x y$ displacement within $10 \mathrm{~m}^{2}$ grid cells, are shown in Fig. 6 for intra- (Fig. 6a, b) and interannual epochs (Fig. 6c). A range of $x y$ displacement orientations are detected and range from sub-centimetre to $>0.2 \mathrm{~m}$ in magnitude. Lateral displacements within season 1 are displayed for both TLSTLS and TLS-SfM differencing products (Fig. 6a and b, respectively).

A comparison of these two datasets reveals similarities but also differences, which also likely arise from data quality issues in the north-west and ice-marginal sectors of the site. Specifically, we cannot confidently corroborate the southerly displacement vectors which are associated with substantial, yet questionable, ice-marginal surface lowering in the TLSSfM data (Fig. 6b). Similarly, the sparsity of TLS data coverage in the western sector of the site makes validation of the northerly vectors associated with surface uplift in the western sector of the site problematic. However, we note that a similar pattern of vertical and lateral displacement is present in the interannual TLS-TLS results in the western sector of the site (Fig. 6c), and so it remains unclear as to whether this surface displacement is an artefact produced by poor data quality. Elsewhere in the embayment, lateral displacements within season 1 exhibit similarities between both sets of differencing data, including a dominantly westward trajectory of surface movement and a localized area of south to southwesterly movement at the extreme rear of the basin which is associated with a general pattern of surface lowering in both datasets (Fig. 6a, b).

In contrast, total $x y$ displacement over a $>1$-year period (Fig. 6c) appears to be less uniform and comparatively chaotic. However, a number of local and largely consistent patterns of horizontal displacement are discernible, such as a predominantly westward movement along the central moraine ridge and north- to north-eastern motion along the western edge of the site (Fig. 6c), which also occurs within season 1 (Fig. 6a). Both trends are associated with net surface uplift. In contrast, isolated patches of surface lowering are generally characterized by southern or south-westerly $x y$ displacement.

The analysis of surface profile transects sheds further light on the evolution of surface topography (Fig. 4). These data are particularly useful for examining the interplay between vertical and lateral moraine surface displacement, which is indicated in Fig. 6. For example, a combination of surface uplift and lateral displacement between the start and end of season 1 is visible between 28 and $40 \mathrm{~m}$ in profile A (Fig. 4, inset 1). Similarly, lateral (southern) translation of the moraine surface between 15 and $22 \mathrm{~m}$ in profile C (Fig. 4, inset 2) is visible for the same differencing epoch. 


\section{Implications for glaciological process analysis}

Here we highlight some implications arising from the measurement of these short-term changes in surface morphology. Topographically, the Patriot Hills blue-ice moraine confirms the morphological observations of the embayment, described by Fogwill et al. (2012) as comprising sloping terraces and blocky, pitted boulder moraine ridges. These ridges are thought to be fed from beneath by steeply dipping debris bands coming from depth, driven by ice-flow compensating for katabatic wind ablation of the glacier. Vieira et al. (2012) classify what we term blue-ice moraines as "supraglacial moraine" and the debris bands in the blue ice outside of the basin as blue-ice moraines. It is from clasts emerging from these bands that Fogwill et al. (2012) have produced their model of blue-ice moraine formation in the basin. The supraglacial moraines of Vieira et al. (2012) are described as slightly creeping debris-mantled slopes - both Fogwill et al. (2012) and Vieira et al. (2012) consider the features in the basin to be active, but without measurements of observations of rates or the nature of change. Our differencing results confirm the hypothesis that these features are active and develop this idea further to demonstrate that moraine slope evolution is active over annual to intra-annual timescales.

Hättestrand and Johansen (2005) discussed the evolution of blue-ice moraine complexes in Dronning Maud Land, Antarctica, and hypothesized that, following ice-marginal deposition of debris when the adjacent ice surface was higher, the subsequent lowering of the exposed ice surface would produce a slope "outwards" from an embayment, followed by gradual movement of material towards the ice margin in a manner similar to that exhibited by active rock glaciers - features that Vieira et al. (2012) interpret in the next basin along the Patriot Hills range. However, whilst the former holds true as an explanation for the general gradient of the Patriot Hills moraine complex (e.g. Fig. 4), our results suggest that the short-term evolution of the moraines does not necessarily conform to the latter hypothesis of such as simple process of consistent downslope movement and in fact exhibits far more dynamic complexity.

The moraine ridges both close to and far from the ice margin emerge as axes of activity and uplift (Fig. 5c), despite initial field observations suggesting that the ridges most distant from the exposed ice surface were older and less active. However, we exercise caution in the interpretation of surface displacements in the western and ice-marginal sectors of the site due to UAV-SfM data quality issues and instead confine our discussion of geomorphological activity to the remaining $\sim 50 \%$ of the basin area, where we retain confidence in the results of TLS-TLS and TLS-SfM differencing.

Fogwill et al. (2012) suggest that once upcoming debris is at a sufficient thickness, wind-driven ablation shuts off. Our observations suggest that if this is the case, these ridges are not left stagnant at this point. The interplay between ice flow and surface elevation lowering by wind, but reduced by thicker debris, may continue despite the possible ages of the surface debris relative to ridges closer to the contemporary blue-ice margin. This activity is not simply confined to "inward" or "outward" movement of moraines within the embayment but also involves a lateral component (Fig. 6). Whilst we are unable to corroborate the substantial surface lowering reported in the TLS-SfM differencing for the icemarginal zone within season 1 (Fig. 5c) and between seasons (Fig. 5e), areas of seemingly persistent uplift are located on the ice-distal face of the central moraine ridge, as well as along moraine ridges toward the rear of the basin. These trends appear in both the TLS-SfM and TLS-TLS differencing results (Figs. 5 and 6).

Similarly, surface lowering appears to operate at the rear, or southern, extent of the basin within season 1 (Fig. 5c, d) and between the beginning of season 1 and the end of season 2 (Fig. 5b). However, it is characterized by surface uplift from the end of season 1 to the end of season 2 (Fig. 5e, f). This surface lowering trend may be the product of focussed katabatic wind-driven sub-debris ice ablation, coincident with a break (reduction) in slope. There may therefore exist an interplay between moraine uplift and sub-debris ice ablation, where the latter dominates over the longest differencing period (Fig. 5b, c). Sedimentological characterization of the moraine basin by Westoby et al. (2015) revealed low median surface grain sizes toward the rear of the basin, which may be indicative of a longer sediment exposure time for, or preferential exposure to, in situ weathering relative to the remainder of the site, leading to the comminution of surficial deposits and the enhancement of sub-debris ice ablation, which promotes terrain relaxation (e.g. Krüger and Kjær, 2000; Schomacker, 2008; Irvine-Fynn et al., 2011; Staines et al., 2015).

Lateral movement within the moraine ridges (Fig. 6) may reflect lateral extension or "stretching" of the ridges as they encroach on the embayment. Such lateral movement is corroborated from the orientation of crevasse-based grooves in the moraine (Fig. 2c). The apparent inward encroachment of the Patriot Hills moraines (Fig. 6) may be the product of the pressure exerted on the moraines by glacier ice flow into the embayment in compensation for preferential ice ablation by katabatic winds, which is consistent with blue-ice moraine formation theory (Fogwill et al., 2012). Finally, the close match of inter-season surface elevation cross profiles (Fig. 5) points to medium-term stability of the moraine system. This conclusion will be investigated through the application of cosmogenic isotope evidence to assess change since the Holocene.

More broadly, this study has demonstrated the potential for the combination of different high-resolution surveying technologies and advanced 3-D topographic differencing methods for elucidating the short-term evolution of glaciated and ice-marginal landscapes. Whilst this study has focussed on the surface evolution of Antarctic blue-ice moraines, the application of 3-D differencing methods to quantify change be- 
tween repeat, accurate topographic surveys has a wide range of potential glaciological applications, which cryospheric researchers have already begun to capitalize on (e.g. Piermattei et al., 2015, Gabbud et al., 2015; Kraaijenbrink et al., 2016). A key contribution of this study to the wider Earth surface dynamics community is the demonstration of truly 3-D differencing methods to reveal not only vertical surface change but also the magnitude and direction of any lateral component to surface movement. Such methods may have particular value for quantifying the 3-D surface evolution of, for example, rock glaciers, degrading ice-cored moraines, or slope instabilities in permafrost regions, where information regarding both vertical and lateral components of landscape development may be both of scientific interest and practical application.

\section{Summary}

This research has employed a combination of TLS and UAV-based SfM-MVS photogrammetry and 3-D differencing methods to quantify the topographic evolution of an Antarctic blue-ice moraine complex over annual and intraannual timescales. The segmentation of lateral and vertical surface displacements reveals site- and local-scale patterns of geomorphometric moraine surface evolution beyond a threshold level of detection (95\% confidence), including largely persistent vertical uplift across the moraine complex, both within a single season and between seasons. This persistent uplift is interspersed with areas (and periods) of surface downwasting, which is largely confined to the rear of the moraine basin for both differencing epochs and to icemarginal regions within season 1; the latter we deem as nonsignificant. Analysis of lateral displacement vectors, which are generally of a much smaller magnitude than vertical displacements, provide further insights into moraine surface evolution.

A number of methodological shortcomings are highlighted. Briefly, these relate to the incomplete spatial coverage afforded by the use of TLS in a topographically complex environment and issues associated with obtaining suitable ground control for SfM-MVS processing and potential implications for the accuracy of SfM-derived topographic data products. This research represents the first successful application of a combination of high-resolution surveying methods for quantifying the topographic evolution of icemarginal topography in this environment. Furthermore, we have demonstrated that, whilst a number of operational considerations must be taken into account at the data collection stage, these technologies are highly appropriate for reconstructing moraine surface topography and for quantifying Earth surface evolution in glaciated landscapes more generally.
Author contributions. S. A. Dunning, J. Woodward, A. Hein, K. Winter, S. M. Marrero and D. E. Sugden collected field data. TLS and SfM data processing and differencing were undertaken by M. J. Westoby. Data analysis was performed by M. J. Westoby, S. A. Dunning and J. Woodward. Manuscript figures were produced by M. J. Westoby. All authors contributed to the writing and revision of the manuscript.

Acknowledgements. The research was funded by the UK Natural Environment Research Council (Research Grants NE/I027576/1, NE/I025840/1, NE/I024194/1, NE/I025263/1). We thank the British Antarctic Survey for logistical support. We thank the reviewers for their constructive comments on the manuscript.

Edited by: J. K. Hillier

\section{References}

Agisoft: Agisoft PhotoScan Professional Edition v.1.1.6., available at: http://www.agisoft.com (last access: 30 April 2016), 2014.

Arnold, N. S., Rees, W. G., Hodson, A. J., and Kohler, J.: Topographic controls on the surface energy balance of a high Arctic valley glacier, J. Geophys. Res., 111, F02011, doi:10.1029/2005JF000426, 2006.

Baltsavias, E. P., Favey, E., Bauder, A., Bösch, H., and Pateraki, M.: Digital surface modelling by airborne laser scanning and digital photogrammetry for glacier monitoring, Photogramm. Rec., 17, 243-273, doi:10.1111/0031-868X.00182, 2001.

Barnhart, T. B. and Crosby, B. T.: Comparing two methods of surface change detection on an evolving thermokarst using hightemporal-frequency terrestrial laser scanning, Selawik River, Alaska, Remote Sensing, 5, 2813-2837, doi:10.3390/rs5062813, 2013.

Bhardwaj, A., Sam, L., Akanksha, A., Martín-Torres, F. J., and Kumar, R.: UAVs as remote sensing platform in glaciology: Present applications and future prospects, Remote Sens. Environ., 175, 196-204, doi:10.1016/j.rse.2015.12.029, 2016.

Bintanja, R.: On the glaciological, meteorological, and climatological significance of Antarctic blue ice areas, Rev. of Geophys., 37, 337-359, doi:10.1029/1999RG900007, 1999.

Bollmann, E., Sailer, R., Briese, C., Stotter, J., and Fritzmann, P.: Potential of airborne laser scanning for geomorphologic feature and process detection and quantifications in high alpine mountains, Z. Geomorphol., 55, 83-104, doi:10.1127/03728854/2011/0055S2-0047, 2011.

Brasington, J., Rumsby, B. T., and McVey, R. A.: Monitoring and modelling morphological change in a braided gravel-bed river using high resolution GPS-based survey, Earth Surf. Proc. Land., 25, 973-990, doi:10.1002/1096-9837(200008)25:9<973::AIDESP111>3.0.CO;2-Y, 2000.

Chandler, B. M. P., Evans, D. J. A., Roberts, D. H., Ewertowski, M., and Clayton, A. I.: Glacial geomorphology of the Skálafellsjökull foreland, Iceland: A case study of "annual" moraines, Journal of Maps, doi:10.1080/17445647.2015.1096216, 2015.

Dunning, S. A., Large, A. R. G., Russell, A. J., Roberts, M. J., Duller, R., Woodward, J., Mériaux, A.-S., Tweed, F. S., and Lim, M.: The role of multiple glacier outburst floods in proglacial 
landscape evolution: The 2010 Eyjafjallajökull eruption, Iceland, Geology, 796, 1123-1136, doi:10.1130/G34665.1, 2013.

Farr, T. G., Rosen, P. A., Caro, E., Crippen, R., Duren, R., Hensley, S., Kobrick, M., Paller, M., Rodriguez, E., Roth, L., Seal, D., Shaffer, S., Shimada, J., Umland, J., Werner, M., Oskin, M., Burbank, D., and Alsdorf, D.: The shuttle radar topography mission, Rev. Geophys., 45, RG2004, doi:10.1029/2005RG000183, 2007.

Fogwill, C. J., Hein, A. S., Bentley, M. J., and Sugden, D. E.: Do blue-ice moraines in the Heritage Range show the West Antarctic ice sheet survived the last interglacial?, Palaeogeogr. Palaeoecl., 335-336, 61-70, doi:10.1016/j.palaeo.2011.01.027, 2012.

Fuller, I. C., Large, A. R. G., and Milan, D.: Quantifying channel development and sediment transfer following chute cutoff in a wandering gravel-bed river, Geomorphology, 54, 307-323, doi:10.1016/S0169-555X(02)00374-4, 2003

Gabbud, C., Micheletti, N., and Lane, S. N.: Lidar measurement of surface melt for a temperate Alpine glacier at the seasonal and hourly scales, J. Glaciol., 61, 963-974, doi:10.3189/2015JoG14J226, 2015.

Hardt, J., Hebenstreit, R., Lüthgens, C., and Böse, M.: Highresolution mapping of ice-marginal landforms in the Barnim region, northeast Germany, Geomorphology, 250, 41-52, doi:10.1016/j.geomorph.2015.07.045, 2015.

Hättestrand, C. and Johansen, N.: Supraglacial moraines in Scharffenbergbotnen, Heimafrontfjella, Dronning Maud Land, Antarctica - significance for reconstructing former blue ice areas, Antarct. Sci., 17, 225-236, doi:10.1017/S0954102005002634, 2005.

Hein, A. S., Woodward, J., Marrero, S. M., Dunning, S. A., Steig, E. J., Freeman, S. P. H. T., Stuart, F. M., Winter, K., Westoby, M. J., and Sugden, D. E.: Evidence for the stability of the West Antarctic Ice Sheet divide for 1.4 million years, Nature Communications, 7, 10325, doi:10/1038/ncomms10325, 2016.

Hodge, R., Brasington, J., and Richards, K.: In-situ characterisation of grain-scale fluvial morphology using Terrestrial Laser Scanning, Earth Sur. Proc. Land., 34, 954-968, doi:10.1002/esp.1780, 2009.

Immerzeel, W. W., Kraaijenbrink, P. D. A., Shea, J. M., Shrestha, A. B., Pellicciotti, F., Bierkens, M. F. P., and de Jong, S. M.: High-resolution monitoring of Himalayan glacier dynamics using unmanned aerial vehicles, Remote Sens. Environ., 150, $93-$ 103, doi:10.1016/j.rse.2014.04.025, 2014.

Irvine-Fynn, T. D. L., Sanz-Ablanedo, E., Rutter, N., Smith, M. W., and Chandler, J. H.: Measuring glacier surface roughness using plot-scale, close-range digital photogrammetry, J. Glaciol., 60, 957-969, doi:10.3189/2014JoG14J032, 2014.

James, M. R. and Robson, S.: Straightforward reconstruction of 3-D surfaces and topography with a camera: accuracy and geoscience application, J. Geophys. Res., 117, F03017, doi:10.1029/2011JF002289, 2012.

James, M. R. and Robson, S.: Mitigating systematic error in topographic models derived from UAV and ground-based image networks, Earth Surf. Proc. Land., 39, 1413-1420, doi:10.1002/esp.3609, 2014.

Javernick, L., Brasington, J., and Caruso, B.: Modelling the topography of shallow braided rivers using Structurefrom-Motion photogrammetry, Geomorphology, 213, 116-182, doi:10.1016/j.geomorph.2014.01.006, 2014.
Kääb, A.: Monitoring high-mountain terrain deformation from repeated air- and spaceborne optical data: examples using digital aerial imagery and ASTER data, ISPRS J. Photogramm., 57, 3952, doi:10.1016/S0924-2716(02)00114-4, 2002.

Kääb, A., Girod, L., and Berthling, I.: Surface kinematics of periglacial sorted circles using structure-from-motion technology, The Cryosphere, 8, 1041-1056, doi:10.5194/tc-8-10412014, 2014.

Keim, R. F., Skaugset, A. E., and Bateman, D. S.: Digital terrain modelling of small stream channels with a total-station theodolite, Adv. Water Resour., 23, 41-48, doi:10.1016/S03091708(99)00007-X, 1999.

Keutterling, A. and Thomas, A.: Monitoring glacier elevation and volume changes with digital photogrammetry and GIS at Gepatschferner glacier, Austria, Int. J. Remote Sens., 27, 43714380, doi:10.1080/01431160600851819, 2006.

Kraaijenbrink, P., Meijer, S. W., Shea, J. M., Pellicciotti, F., de Jong, S. M., and Immerzeel W. W.: Seasonal surface velocities of a Himalayan glacier derived by automated correlation of unmanned aerial vehicle imagery, Ann. of Glaciol., 57, 103-113, doi:10.3189/2016AoG71A072, 2016.

Krüger, J. and Kjær, K. H.: De-icing progression of ice-cored moraines in a humid, subpolar climate, Kötlujökull, Iceland, The Holocene, 10, 737-747, doi:10.1191/09596830094980, 2000.

Lague, D., Brodu, N., and Leroux, J.: Accurate 3-D comparison of complex topography with terrestrial laser scanner: Application to the Rangitikei canyon (N-Z), ISPRS J. Photogramm., 82, 10-26, doi:10.1016/j.isprsjprs.2013.04.009, 2013.

Lewis, A., Hilley, G. E., and Lewicki, J. L.: Integrated thermal infrared imaging and structure-from-motion photogrammetry to map apparent temperature and radiant hydrothermal heat flux at Mammoth Mountain, CA, USA, J. Volcanol. Geoth. Res., 303, 16-24, doi:10.1016/j.jvolgeores.2015.07.025, 2015.

Lowe, D. G.: Distinctive image features from scaleinvariant keypoints, Int. J. Comput. Vision, 60, 91-110, doi:10.1023/B:VISI.0000029664.99615.94, 2004.

Micheletti, N., Chandler, J. H., and Lane, S. N.: Investigating the geomorphological potential of freely available and accessible structure-from-motion photogrammetry using a smartphone, Earth Surf. Proc. Land., 40, 473-486, doi:10.1002/esp.3648, 2014.

Micheletti, N., Lane, S. N., and Chandler, J. H.: Application of archival aerial photogrammetry to quantify climate forcing of Alpine landscapes, Photogramm. Rec., 30, 143-165, doi:10.1111/phor.12099, 2015.

Milan, D. J., Heritage, G. L., and Hetherington, D.: Application of a 3-D laser scanner in the assessment of erosion and deposition volumes and channel change in a proglacial river, Earth Surf. Proc. Land., 32, 1657-1674, doi:10.1002/esp.1592, 2007.

Niethammer, U., Rothmund, S., James, M. R., Traveletti, J., and Joswig, M.: UAV-based remote sensing of landslide. International Archives of the Photogrammetry, Remote Sensing and Spatial Information Sciences, 38, 496-501, doi:10.1016/j.enggeo.2011.03.012, 2010.

Noh, M-J. and Howat, I. M.: Automated stereo-photogrammetric DEM generation at high latitudes: Surface Extraction with TIN-based Search-space Minimization (SETSM) validation and demonstration over glaciated regions, Gisci. Remote Sens., 52, 198-217, doi:10.1080/15481603.2015.1008621, 2015. 
Ouédraogo, M. M., Degré, A., Debouche, C., and Lisein, J.: The evaluation of unmanned aerial system-based photogrammetry and terrestrial laser scanning to generate DEMs of agricultural watersheds, Geomorphology, 214, 339-355, doi:10.1016/j.geomorph.2014.02.016, 2014.

Passalacqua, P., Hillier, J., and Tarolli, P.: Innovative analysis and use of high-resolution DTMs for quantitative interrogation of Earth-surface processes, Earth Surf. Proc. Land., 39, 1400-1403, doi:10.1002/esp.3616, 2014.

Passalacqua, P., Belmont, P., Staley, D. M., Simley, J. D., Arrowsmith, J. R., Bode, C. A., Crosby, C., DeLong, S. B., Glenn, N. F., Kelly, S. A., Lague, D., Sangireddy, H., Schaffrath, K., Tarboton, D. G., Wasklewicz, T., and Wheaton, J. M.: Analyzing high resolution topography for advancing the understanding of mass and energy transfer through landscapes: A review, Earth-Sci. Rev., 148, 174-193, doi:10.1016/j.earscirev.2015.05.012, 2015.

Pepin, N. C., Duane, W. J., Schaefer, M., Pike, G., and Hardy, D. R.: Measuring and modeling the retreat of the summit ice fields on Kilimanjaro, East Africa, Arct. Antarct. Alp. Res., 46, 905-917, doi:10.1657/1938-4246-46.4.905, 2014.

Piermattei, L., Carturan, L., and Guarnieri, A.: Use of terrestrial photogrammetry based on structure-from-motion for mass balance estimation of a small glacier in the Italian alps, Earth Surf. Proc. Land., 40, 1791-1802, doi:10.1002/esp.3756, 2015.

Pitkänen, T. and Kajuutti, K.: Close-range photogrammetry as a tool in glacier change detection. International Archives of the Photogrammetry, Remote Sensing and Spatial Information Sciences (ISPRS), 35, 769-773, 2004.

Reid, T. D., Carenzo, M., Pellicciotti, F., and Brock, B. W.: Including debris cover effects in a distributed model of glacier ablation, J. Geophys. Res.-Atmos., 117, D18105, doi:10.1029/2012JD017795, 2012.

Rippin, D. M., Pomfret, A., and King, N.: High resolution mapping of supra-glacial drainage pathways reveals links between micro-channel drainage density, surface roughness and surface reflectance, Earth Surf. Proc. Land., 40, 1279-1290, doi:10.1002/esp.3719, 2015.

Rosnell, T. and Honkavaara, E.: Point cloud generation from aerial image data acquired by a quadrocopter type micro unmanned aerial vehicle and a digital still camera, Sensors, 12, 453-480, doi:10.3390/s120100453, 2012.

Rosser, N. J., Petley, D. N., Lim, M., Dunning, S. A., and Allison, R. J.: Terrestrial laser scanning for monitoring the process of hard rock coastal cliff erosion, Q. J. Eng. Geol. Hydroge., 38, 363375, 2005.

Ryan, J. C., Hubbard, A. L., Box, J. E., Todd, J., Christoffersen, P., Carr, J. R., Holt, T. O., and Snooke, N.: UAV photogrammetry and structure from motion to assess calving dynamics at Store Glacier, a large outlet draining the Greenland ice sheet, The Cryosphere, 9, 1-11, doi:10.5194/tc-9-1-2015, 2015.

Sanz-Ablanedo, E., Chandler, J. H., and Irvine-Fynn, T. D. L.: Studying glacial melt processes using sub-centimeter DEM extraction and digital close-range photogrammetry, ISPRS Archives, 39, 435-440, 2012.

Schomacker, A.: What controls dead-ice melting under different climate conditions? A discussion, Earth-Sci. Rev., 90, 103-113, doi:10.1016/j.earscirev.2008.08.003, 2008.

Schwalbe, E. and Maas, H. G.: Motion analysis of fast flowing glaciers from multi-temporal terrestrial laser scan- ning, Photogramm. Fernerkund., 1, 91-98, doi:10.1127/09351221/2009/0009, 2009.

Sinisalo, A. and Moore, J. C.: Antarctic blue ice area - towards extracting paleoclimate information, Antarct. Sci., 22, 99-115, doi:10.1017/S0954102009990691, 2010.

Smith, M. J., Rose, J., and Booth, S.: Geomorphological mapping of glacial landforms from remotely sensed data: An evaluation of the principal data sources and an assessment of their quality, Geomorphology, 76, 148-165, doi:10.1016/j.geomorph.2005.11.001, 2006.

Smith, M. J., Rose, J., and Gousie, M. B.: The Cookie Cutter: A method for obtaining a quantitative 3-D description of glacial bedforms, Geomorphology, 108, 209-218, doi:10.1016/j.geomorph.2009.01.006, 2009.

Smith, M. W. and Vericat, D.: From experimental plots to experiment landscapes: topography, erosion and deposition in subhumid badlands from Structure-from-Motion photogrammetry, Earth Surf. Proc. Land., 40, 1656-1671, doi:10.1002/esp.3747, 2015.

Spaulding, N. E., Spikes, V. B., Hamilton, G. S., Mayewski, P. A., Dunbar, N. W., Harvey, R. P., Schutt, J., and Kurbatov, A. V.: Ice motion and mass balance at the Allan Hills blue-ice area, Antarctica, with implications for paleoclimate reconstructions, J. Glaciol., 58, 399-406, doi:10.3189/2012JoG11J176, 2012.

Staines, K. E. H., Carrivick, J. L., Tweed, F. S., Evans, A. J., Russell, A. J., Jóhannesson, T., and Roberts, M.: A multidimensional analysis of pro-glacial landscape change at Sólheimajökull, southern Iceland, Earth Surf. Proc. Land., 40, 809822, doi:10.1002/esp.3662, 2015.

Stumpf, A., Malet, J.-P., Allemand, P., and Ulrich, P.: Surface reconstruction and landslide displacement measurements with Pléiades satellite images. ISPRS Journal of Photogrammetry and Remote Sensing, 95, 1-12, doi:10.1016/j.isprsjprs.2014.05.008, 2014.

Tarolli, P.: High-resolution topography for understanding Earth surface processes: Opportunities and challenges, Geomorphology, 216, 295-312, doi:10.1016/j.geomorph.2014.03.008, 2014.

Tonkin, T. N., Midgley, N. G., Graham, D. J., and Labadz, J. C.: The potential of small unmanned aircraft systems and structurefrom-motion for topographic surveys: a test of emerging integrated approaches at Cwm Idwal, North Wales, Geomorphology, 226, 35-43, doi:10.1016/j.geomorph.2014.07.021, 2014.

Vieira, R., Hinata, S., da Rosa, K. K., Zilberstein, S., and Simoes, J. C.: Periglacial features in Patriot Hills, Ellsworth Mountains, Antarctica, Geomorphology, 155-156, 96-101, doi:10.1016/j.geomorph.2011.12.014, 2012.

Westoby, M. J., Brasington, J., Glasser, N. F., Hambrey, M. J., and Reynolds, J. M.: "Structure-from-Motion" photogrammetry: A low-cost, effective tool for geoscience applications, Geomorphology, 179, 300-314, doi:10.1016/j.geomorph.2012.08.021, 2012.

Westoby, M. J., Dunning, S. A., Woodward, J., Hein, A. S., Marrero, S. M., Winter, K., and Sugden, D. E.: Sedimentological characterisation of Antarctic moraines using UAVs and Structure-from-Motion photogrammetry, J. Glaciol., 61, 1088 1102, doi:10.3189/2015JoG15J086, 2015.

Wheaton, J. M., Brasington, J., Darby, S. E., and Sear, D. A.: Accounting for uncertainty in DEMs from repeat topographic sur- 
veys: improved sediment budgets, Earth Surf. Proc. Land., 35, 136-156, doi:10.1002/esp.1886, 2010.

Whitehead, K., Moorman, B., and Wainstein, P.: Measuring daily surface elevation and velocity variations across a polythermal arctic glacier using ground-based photogrammetry, J. Glaciol., 60, 1208-1220, doi:10.3189/2014JoG14J080, 2014.
Woodget, A. S., Carbonneau, P. E., Visser, F., and Maddock, I. P,: Quantifying submerged fluvial topography using hyperspatial resolution UAS imagery and structure from motion photogrammetry, Earth Surf. Proc. Land., 40, 47-64, doi:10.1002/esp.3613, 2015. 